https://doi.org/10.48009/2_iis_2006_165-170

\title{
E-GOVERNMENT PRACTICES AT LOCAL LEVELS: AN ANALYSIS OF U.S. COUNTIES' WEBSITES
}

\author{
Zhenyu Huang, Central Michigan University, huang1z@ cmich.edu
}

\begin{abstract}
This study presents a comprehensive investigation of U.S. counties' e-government adoption and the functions of the websites. By using content analysis methodology, we scrutinized the services, functions, and features of U.S. county e-government portals. The investigation instrument was established upon political and technological theories, e-government progress models, and comprehensive literature review. The research found that the U.S. counties' adoption of e-government portals was highly associated with certain social and economic factors. The research provides insights for government policy makers to understand, investigate, guide, and regulate e-government practice. It also contributes a benchmark of local e-government website functionalities for researchers in the area.
\end{abstract}

Keywords: E-Government, Content Analysis, County, Local Government, Progress Model

\section{INTRODUCTION}

U.S. governments at all levels strive to improve their service quality in terms of both functionalities and delivery methods by adopting advanced information technologies [2]. When the Internet is widely accepted and used, e-government has been adopted as an efficient approach to support public governance. E-government refers to the transformation of traditional public sector services and processes into an electronic format with greater accessibility and interactivity to citizens [3]. It uses the Internet to bring citizens, businesses, institutions, and governments together.

Currently, most e-government research has focused on federal and state level e-government practices; seldom do studies shed a light on local governments' efforts. Less was systematic empirical analysis of online government services [9]. There are over 3,000 counties in the U.S [13]. It is unknown if these counties have adopted e-government or not, and if yes, to what the extent could the local e-government websites provide services to their citizens. Current literature provides little guidance on local governments' adoption of e-government. Due to the fact that the majority of U.S. citizens are related to and serviced by local governments and a great number of administrative functions were delivered at local levels, it is imperative for us to understand more of the status and progress of local e-government practices.

This research attempts to answer following significant questions:

1. How many U.S. counties have adopted egovernment practices and who are they?

2. Are the counties that adopt e-government different from those that do not? If so, to what extent do they differ over social and economic factors?

3. What characteristics do county e-government portals have?

4. Which e-government service stages have these counties reached?

\section{LITERATURE REVIEW}

During the development of e-government, the government has to undergo various stages of technology implementation and sophistication. According to Huang and Bwoma [3], e-government development follows a stage-model. The major stages include 1) information publishing - the government merely posts information on the websites for the constituents to review, 2) two-way communicationcitizens can communicate with the government and make requests, 3) transaction-websites can accommodate processing of executable transactions, and 4) integration-government services are integrated together. Watson and Mundy [13] introduced the concept of e-democracy, which entails two elements: e-government and e-politics. Whereas e-government provides citizens basic information about the government, e-politics refers to the use of the internet technology to improve the effectiveness of political decision-making by making "citizens aware of the how and why of political decisionmaking and facilitating their participation in this process" (p.28). Consequently, the ultimate objective of e-government is to develop e-democracy which allows both effectiveness and efficiency of governments to serve citizens. 
There are a few studies that have empirically examined the e-government phenomena at the national and international levels (e.g., $[8,12,14])$. Because of dramatic economic, social, political and demographic differences among countries, it is hard to draw a consistent conclusion on what factors really impacted e-government development in different countries. For example, West [14] investigated U.S. federal and state e-government websites for their information, services, privacy \& security, disability access, foreign language support, and democratic outreach. He found that federal government websites did a better job of offering information and services to citizens than did state government websites while overall big improvements could be seen at both levels over years. In addition, West [14] found 25\% of the websites examined offered services that were fully executable online. However, La Porte et al [8] found that a nation's wealth only explained about $30 \%$ of the variation in the number of Web sites across national ministries in their investigation of 192 governments around the world since 1996.

Several studies examined the adoption of egovernment at local levels. Koh and Prybutok [5] used a three-ring model to measure e-government functions which were categorized into informational, transactional, and operational areas. They found that a city's use of the Internet still remained in an early stage of e-government evolution. Musso et al [9] examined the extent to which innovative applications of Web technology might advance local governance reform. They conducted a structured content analysis of 270 California municipal web sites. Based on the analysis results, they concluded that the majority of municipal websites were poorly designed, with few innovative applications of technology and no clear mission. Norris and Moon [11] conducted two nationwide surveys to investigate local government adoption of e-government, web site sophistication, the perceived impacts of e-government, and barriers to the adoption and sophistication of e-government. They found that that e-government adoption by the grassroots governments was progressing rapidly (if measured solely by deployment of Web sites); however, the movement toward integrated and transactional e-government was progressing much more slowly.

\section{METHODOLOGY}

This research investigates the status of U.S. counties' e-government practice using content analysis methodology. Content analysis is a research technique for the objective, systematic, and quantitative description of the manifest content of communicator $[4,7]$. It has been intensively applied in research of consumer behavior, public communications, and media analysis. Recently, it has been frequently used to investigate the Internet usage, e.g., Website content and structure [1]. For government services and functions are delivered via the Internet media, content analysis presents an effective methodology of evaluating e-government practice. Based on a well established four-stage egovernment practice model [3], we establish a research instrument in which the measures of egovernment functions are organized into four categories: information, communication, transaction, and democracy. There are respectively $12,16,5$, and 3 items in these four categories that measure egovernment functions in corresponding aspect. In addition, counties' social and economic factors such as population, racial and cultural, education and income factors are gleaned to support analysis. The unit of analysis is a county's e-government portal.

An e-government portal is as an official entry website that contains information about and links to the services provided by all county departments and agencies. A portal is created from the idea of "onestop service centers" [2]. An e-government portal is an umbrella website where services of different administrative levels, departments, agencies are organized together. U.S. counties are relatively stable administrative units; and a county' mission, tasks, and scope of services are well defined. Therefore, an investigation of U.S. counties' e-government portals can effectively help us understand the status of local governments' adoption of e-government [10]. Fortyeight U.S. states have county governments. Alaska and Louisiana call their county-type government boroughs and parishes respectively. Connecticut, Vermont, and Rhode Island are divided into geographic regions called counties, but these states do not have functioning governments at county levels as defined by the Census Bureau [10]. Boroughs and parishes in Alaska and Louisiana were treated as county governments in this study. All U.S. counties' e-government websites, when available, were coded and analyzed.

The list of U.S. counties is obtained from uscounties.com-a premier website about U.S. local governments; the list was verified against the website of National Association of Counties (naco.org). Totally, there were 3099 counties in 50 U.S. states found and verified by the time of data collection. Most counties' e-government websites, if they existed, could be obtained from the above two websites. Where there was no website listed for a county, the researchers searched Google and another 
search engine (Yahoo or MSN) using the county name in an effort to find its website. All counties' websites were double checked to make sure they were official county portals by following four evaluation criteria. If a website satisfied two or more criteria, it was determined to be the official county egovernment portal. Using these criteria, websites of a single department, often commerce or tourism department, were filtered out. Social and economic factors such as a county's population, education, income etc were collected from U.S. Census Bureau's State \& County QuickFacts website. Totally, there are 15 social and economic factors in the list.

Three trained, independent coders examined and coded U.S. counties' e-government portals from March to August 2005. As suggested by Kolbe and Burnett [6], the author did not participate in the data collection to ensure objectivity and avoid any potential bias. Interjudge reliability was evaluated using coefficient of agreement, which was calculated at $94.7 \%$.

\section{DATA ANALYSIS \& RESULTS}

Of 3099 U.S counties, 1744 have e-government portals, which accounts for $56.3 \%$ of the population. The top 5 states in which counties have highest egovernment presence rates are Delaware (100\%), North Carolina (96.0\%), California (94.8\%), Nevada $(94.1 \%)$, and Wisconsin $(91.7 \%)$. The bottom 5 states in which their counties have lowest e-government presence rates are South Dakota (10.6\%), West Virginia (12.7\%), Oklahoma (13.0\%), Mississippi (14.6\%), and Kentucky (19.2\%). There was no county e-government website found for Connecticut, Rhode Island, and Vermont because townships or municipalities, instead of counties, are major administrative units in these three states.

\section{Adopters vs. Non-adopters}

An independent t-test was conducted to compare the means of two different groups over a series of factors in order to find out what factors distinguish counties in terms of e-government adoption. These factors were categorized into the following groups: People, Ethnic, Education, Housing, Income, Business, and Geography. Each of these factors, according to past studies in the field (e.g., $[5,8,9,11]$ ), can significantly explain e-government adoption rate. The results of the independent t-test show that U.S. counties differ significantly over many of these factors. Those counties that have e-government portals tend to have larger populations than those that do not (mean 2003 population 134,678 vs. 36,706) and faster population increases from 2000 to 2003 $(2.34 \%$ vs. $0.23 \%)$. Racial and cultural factors can also help explain the difference. The counties that had higher percentages of foreign born persons in their populations $(4.39 \%$ vs. $2.17 \%)$ tended to be more likely to adopt e-government portals; counties where languages other than English were spoken more at home tended to be adopting counties $(9.88 \%$ vs. 6.77\%). Citizens' education levels also made a difference. The adopters had more high school graduates $(79.59 \%$ vs. $74.29 \%)$ and more people with bachelor's or higher degrees (18.62\% vs. $13.38 \%)$ than non-adopters.

Household factors were also significant in distinguishing two groups of counties. The median value of housing units was much higher in the counties that adopted e-government than those which had not $(\$ 96,379.47$ vs. $\$ 67,369.59$, nearly $\$ 30,000.00$ difference). However, it is interesting for us to note that home ownership rate was significantly lower in adopter counties (73.35\% vs. $75.23 \%$ ) than non-adopters. E-government adopters and nonadopters were different in income and business factors. The median household income and per capita income was higher in adopter counties than nonadopters $(\$ 38,237.36$ vs. $\$ 31,307.11$ and $\$ 18,679.66$ vs. $\$ 15,805.55$ respectively). Adopter counties had more private nonfarm employees $(53,953$ vs. 12,421$)$ and retail sales per capita $(\$ 8,236.62$ vs. $\$ 6,320.62)$. Though the average adopter county received more federal funds and grants than non-adopters $(\$ 779,747.17$ vs. $\$ 597,930.07)$, this variable was insignificant in distinguishing counties on their egovernment adoption. Also, persons per square mile was not a significant factor for explaining the egovernment adoption phenomenon, though adopter counties had much higher population intensity (820 persons/mile vs. 186 persons/mile).

\section{County E-government Functions}

Table 1 summarizes the percentage of existing portals providing county operational information. A fairly substantial percentage of sites provided general information about county government, news and events, and employment information. Half of the portals provided county maps. In contrast, fewer sites provided the types of specific information that would have the potential for regular citizens to be aware of government operations (e.g., county budget, 38.7\%) and to improve their life decisions (e.g., school information, $30.6 \%$, refuse collection and recycling, $29.8 \%)$. 
Table 1. Local E-Government Websites that Distribute Information

\begin{tabular}{llcc}
\hline Item\# & Definition & Total (1744) & \% \\
\hline I1 & County Mission/history/introduction & 1419 & $81.4 \%$ \\
I2 & County Budget & 720 & $38.7 \%$ \\
I3 & County News and Events & 1166 & $66.9 \%$ \\
I4 & Departments (Clerk, treasurer, sheriff, etc.) & 1501 & $86.1 \%$ \\
I5 & School information & 533 & $30.6 \%$ \\
I6 & Streets \& roads information & 755 & $43.3 \%$ \\
I7 & Parks and recreation & 757 & $43.4 \%$ \\
I8 & Employment Opportunities/ Human Resources & 1080 & $61.9 \%$ \\
I9 & Public Works (Water, Sanitary sewer, storm water, electric) & 686 & $39.3 \%$ \\
I10 & Refuses collection and recycling & 520 & $29.8 \%$ \\
I11 & Zoning \& planning information & 848 & $48.6 \%$ \\
I12 & County Maps (static) & 885 & $50.7 \%$ \\
\hline
\end{tabular}

Table 2 illustrates the two-way communication capabilities provided by county e-government portals. The data shows that county e-government portals were not well designed to facilitate communications between county officials and citizens. Though most sites provided phone numbers and email address of government officials, seldom had they taken advantage of the Internet to facilitate direct online communication between governments and citizens, e.g., automatic email update about county operation and chat rooms etc. Also noticeable is the lack of online disability service and multiple language support.

Table 2. Local E-Government Websites that Support B-2-C Two-way Communication

\begin{tabular}{llcc}
\hline Item\# & Definition & Total (1744) & \% \\
\hline C1 & Contact Phones of government departments/agencies & 1651 & $94.7 \%$ \\
C2 & Email addresses of government departments/agencies & 1242 & $71.2 \%$ \\
C3 & Downloadable forms for manual completion & 1118 & $64.1 \%$ \\
C4 & Uploadable forms (electronic submission) & 261 & $15.0 \%$ \\
C5 & Search engine or site maps (external search engine such as google or yahoo & 671 & $38.5 \%$ \\
& search is not counted!) & 481 & $27.6 \%$ \\
C6 & Interactive GIS & 855 & $49.0 \%$ \\
C7 & Links to Archives (past news, publications) & 500 & $28.7 \%$ \\
C8 & Access to county databases (e.g., owner, property tax information). & 42 & $2.4 \%$ \\
C9 & Disability services (TTY/TDD phones, bobby approved, section 508 compliant) & 42 & $3.0 \%$ \\
C10 & Multiple Language support & 53 & $17.5 \%$ \\
C11 & Ability to complain online & 305 & 71 \\
C12 & Webcasting of County (council) meetings & 110 & $6.3 \%$ \\
C13 & Automatic e-mail update about county's policies, news, events etc. & 171 & $9.8 \%$ \\
C14 & Provision to rate the website (Website evaluation) & 697 & $40 \%$ \\
C15 & Voter registration & 24 & $1.4 \%$ \\
C16 & Discussion groups/chat rooms & & \\
\hline
\end{tabular}

U.S. county e-government websites had limited transactional functions, just as witnessed by other studies [9]. Only $32.1 \%$ of county e-governments could collect local taxes. Other executable functions were even more limited: only $14.5 \%$ endorsed transactions of vital records and $10.0 \%$, online payments for utilities. 
Table 3. Local E-Government Websites that Support Transactions

\begin{tabular}{llcc}
\hline Item\# & Definition & Total (1744) & \% \\
\hline T1 & Transactions of Vital records (birth, marriage, and death) & 253 & $14.5 \%$ \\
T2 & Transactions of license \& permits (business, building, pets, alcohol, hunting, & 206 & $11.8 \%$ \\
& weaponry etc.) & 150 & $8.6 \%$ \\
T3 & Payment for tickets and fines (parking tickets/fines, etc.) & 44 & $32.1 \%$ \\
T4 & Payment for local taxes (note: paying federal and state tax is not a county & & \\
& government function) & 174 & $10 \%$ \\
\hline
\end{tabular}

It seems that counties strived to provide better democracy content and services via their egovernment portals. It might be arguable that the items listed in this category are mainly information distributing or communication functions. However, this group of services, due to its nature, can be separated from other communication services because e-democracy is the ultimate goal of egovernment development [13]. This category provides a good benchmark for future e-government studies that investigate e-democracy functions, e.g., e-voting.

Table 4. Local E-Government Websites that Support E-Democracy

\begin{tabular}{llcc}
\hline Item\# & Definition & Total (1744) & \% \\
D1 & $\begin{array}{l}\text { Election and Voting } \\
\text { Policies }\end{array}$ & 785 & $45.0 \%$ \\
D2 & $\begin{array}{l}\text { Election forms } \\
\text { (e.g., }\end{array}$ & 788 & $45.2 \%$ \\
& $\begin{array}{l}\text { registration forms) } \\
\text { D3 }\end{array}$ & & \\
\hline
\end{tabular}

Lastly, to uncover the development pattern of local egovernment portals, we calculated the average functions provided by county e-government portals at each stage. The results are presented in Table 5 and Figure 1. On average, county e-government portals provided half of the information-distributing, one third of communication, one tenth of executable transactions, and $40.8 \%$ of democracy functions. The evident trend was that most U.S. counties' egovernment adoption was still at the elementary level. Very few portals could reach the transaction stage. By comparing our data with the data presented in West's study [14], it is evident that local governments lag far behind federal and state egovernments' practice.

\section{CONCLUSION}

In this study, we investigated the e-government adoption by 3099 U.S. counties. In all, 56.3\% counties have adopted e-government portals while $44.7 \%$ have not. Content analysis results show that U.S. counties' adoption of e-government is significantly correlated with a county's population, racial, education, household, income, and business factors. The adopter counties tend to have bigger population, and faster population growth, and more diverse racial structures. Their citizens have significantly better education, higher income, and higher employment opportunities. By comparing counties' e-government practices with the established e-government growth model [3], we found that local e-government practice is still at a low level. There is great potential for local governments to improve their services, especially in two-way communication and executable transaction aspects. This research provides a good e-government function instrument for future research that examines local e-government services and functions; especially for those studies that use longitudinal methodologies, this research provides a good benchmark of local e-government functions.

Table 5. Local E-government Practice at 4 Stages

\begin{tabular}{llcc}
\hline Phase & Definition & Total & $\%$ \\
\hline I & Information & 10,870 & $51.9 \%$ \\
C & Communication & 8,252 & $29.6 \%$ \\
T & Transaction & 827 & $9.5 \%$ \\
D & Democracy & 2,135 & $40.8 \%$ \\
\hline
\end{tabular}




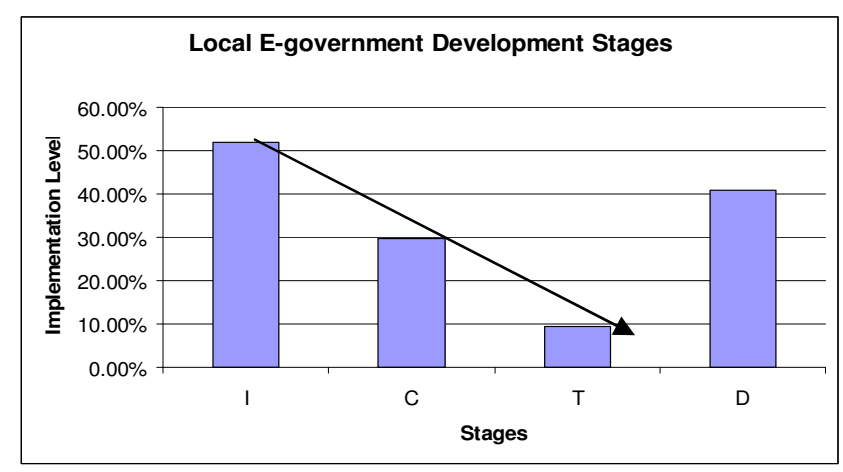

Figure 1. Local E-government Development Stages

\section{REFERENCES}

1. Bauer, C. \& Scharl, A. (2000). Quantitative evaluation of Web site content and structure, Internet Research, 10(1), 31-43.

2. Ho, A.T.K. (2002). Reinventing local governments and the e-government initiative, Public Administration Review, 62(4), 434-444.

3. Huang, Z. \& Bwoma, P.O. (2003). An overview of critical issues of E-government, Issues of Information Systems, 4 (1), 164-170.

4. Kassarjian, H.H. (1977). Content analysis in consumer research, Journal of Consumer Research, 4 (1), 8-18.

5. Koh, C.E. \& Prybutok, V.R. (2003). The three ring model and development of an instrument for measuring dimensions of e-government functions, Journal of Computer Information Systems, 43(3), 34-39.

6. Kolbe, R. H. \& Burnett, M.S. (1991). Contentanalysis research: An examination of applications with directives for improving research reliability and objectivity, Journal of Consumer Research, 18 (2), 243-250.

7. Krippendorff, K. (1980). Content Analysis: An introduction to its methodology, Sage: Beverly Hills, CA.

8. La Porte, T.M., Demchak, C.C. \& Friis, C. (2001). Webbing governance: Global trends across national-level public agencies, Communications of the ACM, 44 (1), 63-67.

9. Musso, J., Weare, C. \& Hale, M. (2000). Designing web technologies for local governance reform: Good management or good democracy? Political Communication, 17 (1), 1-19.

10. NACO. (2005). An Overview of County Government [Electronic Version]. Retrieved January $15, \quad 2005$ from http://www.naco.org/Content/NavigationMenu/A bout_Counties/County_Government/Default271. htm.

11. D.F. Norris D. F. \& Moon, M.J. (2005). Advancing E-government at the grassroots: Tortoise or hare?, Public Administration Review, 65 (1), 64-75.

12. Pons, A. (2004). E-Government for Arab Countries, Journal of Global Information Technology Management, 7 (1), 30 - 46.

13. Watson, R.T. \&. Mundy, B. (2001). A strategic perspective of electronic democracy, Communications of the ACM, 44 (1), 27-30.

14. West, D.M. (2001). State \& Federal EGovernment in the United States, 2001, last accessed: http://www.insidepolitics.org/egovt01us.html. 